\title{
KEARIFAN LOKAL DALAM LEGENDA DAYAK KANAYATN
}

\author{
Sesilia Seli \\ Prodi Pendidikan Bahasa Indonesia, FKIP Untan, Pontianak \\ E-mail: sesiliaseli@yahoo.com
}

\begin{abstract}
Abstrak
Legenda Dayak Kanayatn mencerminkan berbagai ragam peristiwa kehidupan masyarakatnya yang berkaitan dengan word view, ajaran moral, dan berbagai bentuk kearifan lokal yang sangat bermanfaat untuk membentuk perilaku dan pemikiran generasi muda. Sayangnya semakin sedikit generasi muda Dayak Kanayatn yang mewarisi legendanya. Kenyataan ini mendorong peneliti untuk melestarikan legenda Dayak Kanayatn dengan cara mengkaji secara mendalam legenda yang sudah didokumentasikan. Tujuan penelitian ini untuk menganalisis simbol-simbol spiritual dari kearifan lokal dalam legenda Dayak Kanayatn. Teori-teori yang digunakan adalah hermeneutika, simbol, legenda, dan kearifan lokal. Peneliti ini menggunakan metode deskriptif yang berbentuk kualitatif dan pendekatan hermeneutika. Sumber data adalah cerita Ne' Baruakng Kulup dan Ria Sinir. Data dalam penyelidikan ini adalah simbolsimbol spiritual dari kearifan lokal yang tercermin melalui kata, frasa, dan kalimatkalimat yang terdapat dalam cerita Ne' Baruakng Kulup dan Ria Sinir. Hasil analisis terhadap data penelitian menunjukkan bahwa terdapat lima belas buah simbol spiritual yang dikategorikan sebagai: (1) tradisi-tradisi (berkhitan, mengayau, notokng, baliatn, perkawinan, perceraian); (2) kepercayaan (Jubata, nyangahatn, kekuatan gaib, tariu); dan (3) nilai-nilai lokal (musyawarah, solidaritas, patuh pada aturan adat, persahabatan, dan kekerabatan). Kelima belas simbol spiritual tersebut ditafsirkan dan diperoleh 44 makna. Keempat puluh empat makna tersebut dikelompokkan ke dalam lima kategori, yaitu: (1) makna yang berkaitan dengan kepercayaan warisan, (2) makna yang berkaitan dengan tradisi dan adat istiadat, (3) makna yang berkaitan dengan alam sekitar, (4) makna yang berkaitan dengan perilaku hidup bermasyarakat, dan (5) makna yang berkaitan dengan musyawarah.

Kata kunci: legenda, kearifan lokal, hermeneutika, Dayak Kanayatn.
\end{abstract}

\section{PENDAHULUAN}

Kearifan lokal dipahami sebagai nilainilai yang diyakini kebenarannya dan menjadi acuan dalam bartingkah-laku sehari-hari bagi masyarakat setempat. Kearifan lokal merupakan entitas yang sangat menentukan harkat dan martabat manusia, yang berisi unsur kecerdasan, kreativitas, dan pengetahuan lokal dari para elit masyarakat. Kearifan lokal merupakan faktor penentu dalam pem-bangunan peradaban masyarakat. Mengingat pentingnya peranan kearifan lokal dalam hidup bermasyarakat, penulis memandang perlu melakukan penelitian secara lebih intensif terhadap kearifan lokal yang dimiliki oleh komunitas Dayak Kanayatn.

Dalam penelitian ini legenda sebagai korpus kajian. Legenda merupakan satu di antara genre cerita rakyat yang dianggap sebagai warisan kuno, mencakup hal-hal yang luar biasa, dan dianggap benar terjadi oleh pendukung-nya (Dorson, 1972:159). Bahkan, legenda dipandang sebagai peristiwa sejarah yang disebut Hutomo (1991:64) sebagai sejarah rakyat sehingga diyakini kebenarannya. Legenda yang dikaji dalam penelitian ini adalah legenda Ne' Baruakng Kulup dan Ria Sinir. Kedua cerita ini bercirikan seperti ciri cerita rakyat yang dikemukakan 
Danandjaja (1994:3-5); Endraswara (2008:151); dan Shiple et al (1962:102).

Legenda sebagai bentuk sastra lisan dan produk budaya, sarat dengan berbagai simbol yang perlu dimaknai agar diperoleh pesan moral yang dikandungnya. Penelitian ini difokuskan pada simbol-simbol spiritual yang menunjukkan kearifan lokal komunitas Dayak Kanayatn. Simbol-simbol yang dianalisis terkategori sebagai kepercayaan, tradisi, dan nilai-nilai lokal yang tergambar dalam legenda Dayak Kanayatn. Ketiga elemen simbol spiritual ini kemudian dimaknai secara mendalam dengan menggunakan pendekatan hermeneutika menurut pemikiran Paul Ricoeur.

Masalah umum dalam penelitian ini berkaitan dengan simbol-simbol spiritual yang menunjukkan kearifan lokal dalam kegenda Dayak Kanayatn. Masalah umum tersebut dibatasi menjadi masalah khusus berikut ini: (1) Tradisi-tradisi yang menunjukkan kearifan lokal dalam legenda Dayak Kanayatn; (2) Kepercayaan yang menunjukkan kearifan lokal dalam legenda Dayak Kanayatn; (3) Nilai-nilai lokal yang menunjukkan kearifan lokal dalam legenda Dayak Kanayatn; dan (4) Makna simbol-simbol spiritual yang menunjukkan kearifan lokal dalam legenda Dayak Kanayatn

Hermeneutika secara luas dikenal sebagai ilmu penafsiran/interpretasi terhadap teks pada khususnya dan penafsiran terhadap bahasa pada umumnya. Hermeneutika, yang dalam bahasa Inggrisnya hermeneutics, berasal dari bahasa Yunani hermeneutine dan hermeneia yang masing-masing bermaksud "menafsirkan" dan "penafsiran".

Dalam hubungan tersebut, perlu juga disebut seorang tokoh bernama Paul Ricoeur. Beliau adalah seorang tokoh setelah Gadamer yang dalam perkembangan mutakhir banyak mengembangkan hermeneutika dalam bidang sastra dan meneruskan pemikiran falsafah fenomenologis. Menariknya, Ricoeur me-nyatakan bahwa setiap pertanyaan yang diajukan yang berkenaan dengan teks yang akan diinterpretasi adalah sebuah pertanyaan tentang arti dan makna teks. Arti dan makna teks itu diperoleh dari upaya pencarian dalam teks berdasarkan bentuk, sejarah, pengalaman membaca, dan self-reflection dari pelaku interpretasi (Valdes, 1987:60). Bagi Ricoeur, membaca sastra melibatkan pembaca dalam aktivitas refigurasi dunia, dan sebagai konsekuensi dari aktivittas ini, berbagai pertanyaan moral, filosofis, dan estetis tentang dunia tindakan menjadi pertanyaan yang harus dijawab (Valdes, 1987:64).

Ricoeur (1981:145) mendefinisikan hermeneutika sebagai teori tentang bekerjanya pemahaman dalam mentafsirkan teks. Teks dipahami sebagai bentuk realitas wacana. Bagi Ricoeur antara penjelasan (explanation) dengan pemahaman (under-standing), perlu dijelaskan dengan teliti karena kedua-dua hal tersebut menimbulkan banyak persoalan. Menurut Ricoeur (1981:131) hermeneutika bertujuan untuk menggali makna yang terdapat pada teks dan simbol dengan cara menggali tanpa henti makna-makna yang tersembunyi atau-pun yang belum diketahui dalam suatu teks. Penggalian terhadap makna secara berterusan harus dilakukan memandangkan interpretasi dalam teks bukanlah merupakan interpretasi yang bersifat mutlak dan tunggal, melainkan bersifat sementara, kontekstual, dan multi-interpretasi. Seorang penafsir perlu menerap-kan hermeneutika secara kritis agar selalu kontekstual. Penafsir mesti menyadari bahwa interpretasi teks pada dasarnya bersifat dinamik. Makna sesebuah teks akan berbeda ketika dihubungkaitkan dengan konteks yang lain sehingga akan memperkaya penafsiran dan makna. Menurut Ricoeur tugas utama hermeneutika adalah memahami teks. Oleh karena itu, pengertian tentang teks merupakan perbincangan yang sangat penting dalam pemikiran hermeneutika Ricoeur (Moelyono, 1912). Menurut Ricoeur (1995:145) teks adalah "any discourse fixed by writing." Dalam hal ini, Ricoeur (1995:165-168) memahami istilah discourse sebagai event bukan meaning, yaitu bahasa yang membicarakan tentang sesuatu, bahasa yang digunakan dalam berkomunikasi baik secara lisan maupun secara tertulis. Bahasa sebagai meaning adalah bahasa dalam dimensi non-historis, dimensi statik, manakal sebagai event, bahasa dimaknai sebagai bahasa yang hidup, yang dinamis. 
Ricoeur memberikan makna teks dalam pengertian yang lebih luas. Teks tidak hanya terbatas pada bahasa yang diwujudkan dalam tulisan, tetapi mencakupi setiap tindakan manusia yang mempunyai makna, setiap tindakan yang sengaja dilakukan untuk mencapai tujuan tertentu, bahkan realiti sosial menurut Ricoeur memiliki persamaan dengan teks. Realita sosial dapat dijadikan objek kajian ilmiah apabila menjadi baku dalam struktur seperti halnya wacana yang membaku dalam tulisan. Makna sebuah teks tidak lagi bergantung pada pemahaman terhadap kehebatan psikologi pengarangnya. Makna teks tidak lagi terikat pada konteks awalnya, tetapi penafsir kemudian terbuka pada makna-makna baru karena teks telah memiliki makna internal yang objektif. Dalam hal ini, pembaca membuka dirinya di hadapan teks dan teks juga membuka membuka diri untuk dimaknai. Makna sebuah teks bukannya berada di balik atau dibelakang teks, tetapi ada di hadapannya seperti yang dikemukakan Ricoeur (1995:177) sebagai berikut, "Beyond my situation as reader, beyond the situation of the authhor, I offer myself to the possible mode of being-in-the-world which the text opened up and disclose to me."

Penelitian ini menggunakan teori hermeneutika sebagai pendekatan kajian dengan partimbangan bahwa teori ini merupakan salah satu model yang cukup representatif dalam kajian sastra. Tambahan pula, pada dasarnya kajian sastra itu sendiri sebenarnya tidak terlepas dari penafsiran yang mendalam terhadap teks sastra. Teks tidak mungkin diartikan tanpa melalui penafsiran. Ketidakmungkinan tersebut selain disebabkan oleh situasi bahasa yang berbeda dan terus berubah, juga karena kesukaran para pembaca memahami hakikat makna yang terkandung dalam teks dan bahasa yang digunakan. Kesulitan utama dalam memahami makna teks juga karena pada realitinya, bahasa mempunyai keterbatasan dalam mengungkapkan amanat yang dikandungi teks. Disebabkan keterbatasan tersebut, maka kajian yang mendalam perlu dilakukan untuk memahami makna yang tersirat dalam kata atau kalimat yang tersurat. Pemilihan model kajian ini berdasarkan pada cara kerja yang ditawarkan dan pandangan Paul
Ricoeur mengenai teks yang dinilai paling sesuai untuk menganalisis teks legenda Dayak Kanayatn. Selain itu, Paul Ricoeur dinilai sebagai ahli falsafah kontemporer yang menjadi penghubung sekaligus pembeda bagi aliran-aliran antara dua tradisi falsafah besar, yaitu fenomenologis Jerman dan strukturalisme Perancis. Horizon pemikiran Paul Ricoeur merangkum hampir semua topik filsafat kontemporer yang membolehkan dirinya dinobatkan sebagai pemenang hadiah Balzan Price for Philisiphy pada tahun 1999. Menurut Blaicher (1980:233-235) pemikiran Ricoeur dapat dianggap menghubungkan perdebatan sengit dalam peta hermeneutika antara tradisi metodologi dan tradisi falsafah yang masingmasing diwakili oleh Emilio Beti dan HansGeorg Gadamer.

Menurut Ricoeur (1985:52-53), cerita ditulis dalam rangka membicarakan bagaimana manusia menghayati waktu. Waktu hanya dapat dirasakan dan ditanggung oleh manusia ketika waktu itu dibuat teratur di dalam cerita. Bagaimana cerita terjadi? Cerita terjadi melalui proses mimesis. Secara harfiah, mimesis bermaksud meniru. Konsep ini berasaskan kepada interpretasi beliau terhadap Poetica Aristoteles. Mimesis yang dimaksudkannya adalah dalam arti kata meniru secara kreatif dengan membuat kembali yang ditiru dengan lebih teratur dan menarik. Peniruan ini disebut beliau sebagai konfigurasi.

Mimesis menurut beliau terdiri dari tiga tahap, yaitu mimesis ${ }^{1}$, mimesis ${ }^{2}$, dan mimesis ${ }^{3}$. Mimesis $^{1}$ juga dikenali sebagai prefigurasi. Mimesis $^{1}$ ini berupa tindakan-tindakan (action) manusia yang konkrit dalam dunia yang konkrit. Tindakan-tindakan manusia yang konkrit kemudian diatur dan disusun kembali melalui plot (emplotment) maupun unsur-unsur cerita yang lain seperti tokoh, karakter, setting, gaya, dan sebagai-nya. Pengaturan terutamanya dalam plot ini dinamakan mimesis ${ }^{2}$ atau konfigurasi. Proses konfigurasi adalah proses "seeing as", yaitu "melihat sebagai", atau lebih tepat "melihat tindakan-tindakan manusia sebagai". Bagi penulis cerita, proses ini merupakan proses penciptaan makna (sense) melalui kegiatan semantik. Bagi pembaca juga proses ini merupakan penciptaan makna (sense). Sekiranya pembaca tidak 
membaca cerita tersebut, maka makna (sense) pun tidak akan muncul (Ricoeur, 1991:56-57).

Tahap berikutnya adalah mimesis ${ }^{3}$ yang disebut Ricoeur sebagai tahap refigurasi. Kegiatan membaca atau meng-interpretasi memberi orientasi baharu kepada pembaca tentang bagaimana manusia hadir melalui tindakantindakannya dalam dunia nyata. Keberadaannya di dunia melalui tindakan-tindakan direfigurasi, diberi figur yang baru. Pembaca berada (eksis) secara baharu dan mendasar di dunia melalui tindakan-tindakan baru (inisiatif) dan termasuk di dalumumnya tindakan-tindakan etis (eksistensi). Yang diciptakan oleh cerita bukan makna (sense) tetapi reference. Manusia dikirim kembali ke dunia nyata setelah ditarik ke dalam dunia cerita.

Kaitan antara mimesis ${ }^{1}$ dan mimesis ${ }^{3}$ hanya boleh dipahami dengan melakukan mimesis ${ }^{2}$, seperti yang dijelaskan Ricoeur (1991:151) seperti berikut.

To do this, we must balance the autarchy of a theory of writing through a theory of reading and understand that the operating of writing is fulfilled in the operating of reading. Indeed, it is the reader-or rather the act of reading - that, in the final analysis, is the unique operator of the unceasing passage from mimesis ${ }^{1}$ to mimesis ${ }^{3}$ through mimesis ${ }^{2}$. That is, from a prefigured world to a transfigured world through the mediation of a configured world.

Setiap interpretasi menurut Ricouer (dalam Kaelan, 2009:306) adalah suatu usaha untuk 'membongkar' makna-makna yang masih terselubung atau usaha-usaha membongkar lipatan-lipatan dari tingkat-tingkat makna yang terkandung dalam makna kesusastraan. Kata-kata adalah simbol-simbol dan interpretasi merupakan konsep-konsep yang mempunyai banyak makna yang terkandung di dalam simbol-simbol atau kata-kata sebagai ungkapan yang berupa bahasa.

Pendapat Ricoeur (dalam Valdes, 1967:64) mengarah pada sesuatu pandangan bahwa interpretasi digunakan untuk mewujudkan jenis being-in-the-world (dasein) yang terungkap dalam teks dan melalui teks. Dengan demikian, dapatlah dikatakan secara tegas bahwa pemahaman yang paling baik akan terjadi ketika interpreter berdiri pada self-understanding. Membaca sastra menurut Paul Ricouer adalah aktivitas yang melibatkan pembaca dalam aktivitas refigurasi dunia, dan konsekuensi-nya, pelbagai soalan moral, filosofis, dan estetis tentang dunia aktivitas menjadi soalan yang harus dijawab.

Makna sebuah teks tidak akan diperoleh jika tidak membuat pembacaan dan interpretasi terhadap teks tersebut. Ricoeur mengajukan prosedur kerja yang dinama-kannya "depth semantic" yang menempatkan explanation dan interpretation pada garis yang linear. Analisis explanation boleh digunakan sebagai tahap awal untuk mengkaji dimensi statik teks, manakala interpretation digunakan untuk menangkap makna kontekstual dari teks tersebut (dalam Hery dan Mohammed, 2003:223). Sesuai dengan penjelasan tersebut, Paul Ricoeur (1975:161-162) mengatakan, “... to explain is to bring out the structure, that is, the internal relations of dependence which constitute the static of the text; to interpret is to follow the path of thought opened up by the text, to place oneself en route toward the orient of the text."

Tujuan menjelaskan (explanation) yang terjadi dalam tindakan membaca adalah untuk menangkap makna, yaitu sense dan sense ini dicipta oleh mimesis ${ }^{2}$ (konfigurasi). Sense boleh ditangkap melalui analisis semantik. Dalam hal ini, explanation dijalan-kan dengan menganalisis semantik cerita melalui plot, tokoh, setting, gaya, dan sebagainya. Tahap ini dinamakan tahap semantik. Kegiatan menginterpretasi tidak berhenti pada menangkap sense yang dicipta oleh mimesis ${ }^{2}$ sahaja, interpretasi juga bertujuan untuk menangkap reference yang ditimbulkan oleh mimesis ${ }^{3}$ melalui apa yang disebut memahami/ mengerti (understanding). Pemahaman mengenai sense menghantar pembaca kembali kepada keberadaannya dalam dunia nyata yang dirujuk oleh teks cerita. Tahap ini juga dinamakan sebagai tahap eksistensial. Melalui cerita, pembaca atau penafsir didorong untuk berada secara baharu dalam dunia. Pembaca memperoleh orientasi baharu berkenaan cara hidup di dunia.

Understanding (mengerti) tidak hanya bermakna memahamireference, tetapi mengerti diri secara baharu. Lebih tepat lagi, cerita memberi 
diri (self) yang baharu kepada pembaca setelah diri (self) yang lama dipersoalkan dan dibongkar oleh teks cerita yang dibaca. Apa yang selama ini menjadi sifat atau karakter pembaca, diperbaiki secara senyap oleh cerita dalam kegiatan membaca. Maka, sebenarnya penafsiran bukan hanya dilakukan oleh pembaca terhadap teks, tetapi teks juga mentafsir pembaca. Kegiatan ini dinamakan tahap reflektif. Secara sederhana dapat dikatakan bahwa pembaca/penafsir bercermin melalui cerita.

Sebuah interpretasi dalam teks sastra bukanlah merupakan interpretasi yang bersifat definitif, tetapi perlu dilakukan secara terusmenerus, karena interpretasi terhadap teks itu sebenarnya tidak pernah tuntas dan selesai. Dengan demikian, setiap teks sastra sentiasa terbuka untuk diinter-pretasi secara berterusan. Proses pemahaman dan interpretasi teks bukanlah merupakan suatu upaya menghidupkan kembali atau reproduksi, tetapi upaya rekreatif dan produktif. Konsekuensinya, maka fungsi subjek sangat berperanan menentukan interpretasi teks sebagai pemberi makna. Oleh sebab itu, penting sekiranya menyedari bahwa penafsir perlu membawa aktualitas kehidupannya sendiri secara intim berdasar-kan maklumat yang dimunculkan oleh objek tersebut kepadanya. Secara keseluruhannya, dapatlah dinyatakan bahwa hermeneutika memang dapat diterapkan dalam meng-interpretasi sastra. Dalam hal ini, hermeneutika tidak lagi hanya diletakkan dalam kerangka metodologi, tetapi telah mengikuti pemikiran hermeneutika mutakhir yang berada dalam kerangka ontologis.

Menurut Ricoeur (2000:116) bagi membolehkannya sampai kepada penafsiran yang tepat, seorang penafsir harus meng-ambil jarak tertentu dengan objek tafsiran. Ini yang disebut oleh Ricoeur sebagai "perjuang-an melawan distansi kultural". Usaha ini tidak mudah. Kerap kali seorang penafsir membawa bersama struktur-struktur yang sudah "jadi” tentang objek tafsir sehingga sebelum mentafsir sudah ada "warna" yang diberikan kepada objek tersebut. Sekiranya pewarnaan tersebut berlaku, maka ada kemungkinan usaha untuk mencapai makna yang sejati akan menemui kekangan. Penafsir boleh tersesat dengan memberi makna (lain atau berbeda sama sekali) kepada objek, dan bukannya memetik makna yang sudah ada dalam objek tersebut.

Kata simbol dalam bahasa Inggeris disebut symbol yang bermaksud sesuatu yang menggambarkan sesuatu, khususnya untuk menggambarkan sesuatu yang in material, abstrak, suatu idea, kualiti, tanda-tanda suatu objek, dan lain-lain (Coulson et.al vol II 1689). Ardhendu Sekhar Gosh (Titib, 2001:63) menyatakan bahwa kata simbol be-rasal dari kata "symbolon" (dalam bahasa Greek) yang bermaksud tanda. Melalui tanda, seseorang dapat mengetahui atau membuat kesimpulan tentang sesuatu. Dalam bahasa Sanskrit, kata simbol adalah 'pratika' yang bermaksud "yang datang ke depan, yang mendekati”. Oleh yang demikian, simbol boleh dikatakan mengandungi makna yang menunjukkan sesuatu, menampilkan atau menarik kembali sesuatu dengan analogi kualiti kepemilikan atau dengan meng-asosiasikannya ke dalam fakta atau pikiran.

Menurut Spradley (2007:134) ter-dapat tiga unsur yang selalu berkaitan dengan simbol dan mendasari semua makna simbolik, yaitu (1) simbol itu sendiri, (2) satu rujukan atau lebih, dan (3) hubungan antara simbol dan rujukan. Unsur yang pertama meliputi apa sahaja yang dialami, unsur yang kedua adalah benda yang menjadi rujukan simbol yang berupa apa sahaja yang dapat difikirkan manusia, misalnya pohon, binatang, ataupun makhluk mistik yang tidak pernah ada. Unsur yang ketiga, yaitu hubungan antara simbol dan rujukan dimana hubungan ini merupakan hubungan yang berubah-ubah, yang di dalamnya rujukan dikodekan dalam simbol tersebut.

Ricoeur (dalam Sumaryono. 1999: 105) menjelaskan bahwa kata-kata adalah simbol yang menggambarkan makna lain yang sifatnya tidak langsung, tidak begitu penting, serta figuratif (berupa kiasan) dan hanya dapat difahami melalui simbol-simbol tersebut. Oleh sebab itu, interpretasi diperluk-an untuk membongkar maknamakna yang masih terselubung atau membuka lipatan-lipatan dari tingkat-tingkat makna yang terkandung dalam makna kesusastraan. Hidayat (2012:8) mengemukakan bahwa pada hakikatnya 
simbol menerangkan adanya bentuk analogi. Bentuk analogi inilah yang dapat membentuk simbol untuk meng-ilustrasikan pemikiran atau realiti imaginasi. Simbol tidak hanya wujud dalam proses semantik, tetapi juga dalam proses non-semantik. Secara khususnya, simbol wujud berdasarkan hubungan antara manusia, ruangwaktu, dan alam semesta yang dinama-kan triple korepondensi. Hal ini menegaskan bahwa simbol mengandungi pemikiran dengan merujuk kepada konteks dan kontekstualisasi.

Berdasarkan beberapa pendapat tersebut dapatlah difahami bahwa simboladalah suatu tanda yang bersifat ekspresif dan mengkomunikasikan banyak arti. Simbol mewakili pemikiran dan nilai-nilai tertentu yang merujuk pada konteks dan konteks-tualisasi. Dalam memahami dan memaknai sesebuah simbol diperlukan penafsiran dengan merujuk kepada konteks linguistik dan non-linguistik sehingga dapat diperoleh maknaterdalam dari simbol-simbol tersebut.

Berdasarkan wujudnya, simbol dibedakan menjadi simbol material dan inmaterial. Menurut Sobur (2001:156) simbol material adalah simbolsimbol yang me-ngandung hal-hal yang dapat dilihat dan disentuh, yang dapat diartikan sebagai hal-hal yang memiliki unsur fisik. Simbol material pada umumnya berupa benda-benda. Simbol immaterial merupakan simbol-simbol yang tidak nyata sehingga tidak dapat dilihat secara fisik, namun dapat dipahami ketika dilaksanakan atau dilakukan.

Dalam penelitian ini, digunakan istilah simbol fisik untuk menyatakan simbol material dan simbol spiritual untuk me-nyatakan simbol immaterial untuk meng-klasifikasikan simbol berdasarkan wujudnya. Yang tergolong sebagai simbol fisik ialah semua simbol yang berupa benda, seperti bangunan, kerajinan tangan, perkakas rumah tangga, makanan tradisional, hasil pertanian, hutan, hewan, dan semua simbol yang berbentuk fisik. Simbol spiritual pula ialah simbol-simbol yang berkaitan dengan hal-hal yang bersifat batiniah dan kerohanian, seperti pemikiran, padangan, gagasan, nilai-nilai, dan hal lain yang bersifat abstrak.

Legenda. Cerita rakyat yang pada umumnya berbentuk sastra lisan, merupakan bahagian dari tradisi lisan. Francis Lee Utley (Dandess, 1965:7-9) menyebut istilah ini dengan literature transmited orally atau unwritten literature. Hutomo (1991:1) mengatakan bahwa sastra lisan adalah kesusastraan yang mencakup ekspresi kesusastraan warga suatu kebudayaan yang disebarkan dan diturun-temurunkan secara lisan (dari mulut ke mulut). Sebagai bagian dari sastra lisan, cerita rakyat dipandang sebagai dokumen sosial karena mengandung berbagai masalah sosial yang terjadi di dalam masyarakat pemiliknya. Cerita rakyat sebagai bagian dari sastra lisan menurut Endraswara (2008: 151) memiliki ciri-ciri sebagai berikut.

(1) Lahir dari masyarakat yang bersahaja, belum melek huruf, dan bersifat tradisional; (2) menggambarkan budaya milik kolektif tertentu yang tak jelas siapa penciptanya; (3) lebih menekankan aspek khayalan, ada sindiran, jenaka, dan unsur mendidik; (4) sering melukiskan tradisi kolektif tertentu; dan (5) banyak mengungkapkan kata-kata atau ungkapan-ungkapan klise.

Dalam kesusastraan Melayu, Piah (2006:12) membahagi sastra rakyat ke dalam dua bentuk, yaitu sastra rakyat berbentuk cerita dan sastra rakyat berbentuk bukan cerita. Cerita rakyat berbentuk cerita meliputi cerita asal-usul, cerita binatang, cerita jenaka, cerita mitos dan legenda, dan cerita romantis atau pelipur lara (termasuk syair dan prosa lirik) sedangkan yang berbentuk bukan cerita adalah peribahasa, pantun, teromba, matera, zikir, dikir, gurindam, seloka, dan tekateki.

Berdasarkan bahannya, Hutomo (1991:62) membagi cerita rakyat menjadi tiga bagian, yaitu:

(1) Bahan yang bercorak ceritera: (a) ceritera-ceritera biasa (tales), (b) mitos (myth), (c) legenda (legends), (d) epik (epic), (e) cerita tutur (ballads), (f) memori (memorates).

(2) Bahan yang bercorak bukan cerita: (a) ungkapan (folk speech), (b) nyanyian (song), (c) peribahasa (proverbs), (d) teka-teki (riddles), (e) puisi lisan (rhymes), (f) nyanyian sedih pemakaman (dirge), (g) undang-undang atau peraturan adat (low) 
(3) Bahan yang bercorak tingkah laku (drama): (a) drama panggung dan drama arena.

Mencermati pendapat Hutomo tersebut, jelaslah bahwa legenda merupakan satu di antara genre cerita rakyat yang dipandang sebagai warisan leluhur yang dapat digunakan untuk menyampaikan sikap takhyul dan sikap hidup yang lebih asli kepada kita (Krohn, 1971:20). Cerita-cerita yang tergolong dalam legenda mencakup hal-hal yang luar biasa dan dianggap benar oleh pendukungnya (Dorson, 1968:159). Bahkan, legenda dipandang sebagai peristiwa sejarah yang disebut Hutomo (1991: 64) sebagai sejarah rakyat sehingga diyakini kebenaran-nya. Dengan demikian dapat dikatakan bahwa legenda merupakan satu diantara genre cerita rakyat yang mencakup hal-hal yang luar biasa dan terjadi di dalam dunia nyata. Selanjutnya Moeis (1991:37) mengata-kan bahwa legenda bukan semata-mata cerita hiburan, namun lebih dari itu. Legenda berfungsi untuk mendidik dan membekali manusia, terutama komunitas pemiliknya agar terhindar dari ancaman marabahaya.

Legenda biasanya bersifat migratoris, maksudnya dapat berpindah-pindah sehingga dikenal luas di daerah-daerah yang berbeda. Selain itu legenda sering kali tersebar dalam bentuk pengelompokan yang dinamakan siklus (cycle), yaitu sekelompok cerita yang berkisar pada suatu tokoh atau suatu kejadian tertentu. Legenda oleh masyarakat pen-dukungnya dianggap sebagai peristiwa-peristiwa sejarah sehingga Hutomo (1991:64) menamakannya sebagai sejarah rakyat.

Brunvand (dalam Danandjaja, 1984:67) menggolongkan legenda ke dalam empat kelompok, yaitu "(1) legenda keagamaan (religious legend); (2) legenda alam gaib (supernatural legend); (3) legenda perseorangan (personal legend); dan (4) legenda setempat (local legend)". Legenda keagamaan adalah legenda tentang orang-orang suci (dalam agama Nasrani); orang-orang saleh seperti legenda para Wali dalam agama Islam. Legenda alam gaib (aemorat) adalah legenda yang berisi pengalaman seseorang yang berkaitan dengan erat dengan suatu kepercayaan. Fungsinya adalah untuk meneguhkan kebenaran takhyul atau kepercayaan rakyat. Legenda perseorangan adalah cerita mengenai tokoh-tokoh tertentu yang dianggap oleh yang empunya cerita benar-benar pernah terjadi. Legenda setempat adalah cerita yang berhubungan dengan suatu tempat, nama tempat atau tipografi, yakni bentuk permukaan suatu daerah, apakah berbukit-bukit, berjurang, dan sebagainya.

Berdasarkan beberapa pendapat tersebut, dapat disimpulkan bahwa legenda merupakan satu di antara genre cerita rakyat yang menceritakan hal-hal yang luar biasa dan terjadi dalam dunia nyata. Legenda dipandang sebagai sejarah masyarakat sehingga diyakini kebenarannya. Legendaberfungsiuntukmendidik dan membekali manusia agar terhindar dari ancaman marabahaya. Berdasarkan isinya legenda dibedakan menjadi legenda keagamaan, legendaalam gaib, legenda perseorangan, dan legenda setempat.

Kearifan Lokal. Istilah kearifan lokal (local genius) pertamakali digunakan oleh H.G. Quaritch Wales dalam artikelnya yang berjudul Culture Change in Greater India pada tahun 1948, yang dimuat pada Journal of Royal Asiatic Society. Istilah tersebut dapat juga ditemukan dalam bukunya yang berjudul The Makin of Greater India: A Study in South-East Asia Culture Change yang terbit pada tahun 1951. H.G. Quaritch Wales memaknai kearifan lokal sebagai, "the sum of the cultural characteristics which the vast majority of a people have in cammon as a result of their experience in early life." (keseluruhan ciri kebudayaan yang dimiliki bersama oleh suatu masyarakat sebagai hasil pengalaman mereka sepanjang hidup). Lebih lanjut dijelaskannya bahwa kearifan lokal merupakan kemampuan kebudayaan lokal dalam menghadapi pengaruh kebudayaan asing pada saat kedua kebudayaan itu bertemu (Ayatrohaedi, 1986:18).

Rosidi (2011:9) juga menjelaskan bahwa H.G. Quaritch Waleslah orang yang mula pertama mengenalkan istilah kearifan lokal. "Saya kira istilah kearifan lokal merupakan terjemahan dari local genius yang diperkenalkan pertama kali oleh Quaritch Wales (1948-1949) dengan arti kemampuan kebudayaan setempat dalam menghadapi pengaruh kebudayaan asing pada waktu kedua kebudayaan itu bertembung." 
Menurut Haryati Soebadio (dalam Mariane, 2014:112) local genius adalah juga local indentity, identiti kepribadian budaya bangsa yang menyebabkan bangsa tersebut mampu menyerap dan mengolah kebudayaan asing sesuai watak dan kemampuannya sendiri. Menurut Mundardjito unsur budaya daerah berpeluang untuk menjadi kearifan lokal karena telah teruji kemampuannya untuk bertahan sampai sekarang.

Adapaun ciri-ciri kearifan lokal menurut Ayatrohaedi (1986:40-41) adalah sebagai berikut: (1) Mampu bertahan terhadap budaya luar; (2) Memiliki kemampuan meng-akomodasi unsurunsur budaya luar; (3) Mempunyai kemampuan untuk mengintegrasikan usnur budaya luar ke dalam budaya asli; (4) Mempunyai kemampuan untuk mengendalikan; dan (5) Mampu memberi arah pada perkembangan budaya.

Kearifan lokal juga dimaknai sebagai pandangan hidup dan pengetahuan serta berbagai cara menjalankan kehidupan yang wujud sebagai aktivitas yang dilakukan oleh masyarakat lokal dalam menjawab berbagai masalah dalam pemenuhan keperluan hidup mereka. Sistem pemenuhan keperluan hidup mereka pasti meliputi seluruh kehiduan; agama, ilmu pengetahuan, ekonomi, tek-nologi, organisasi sosial, bahasa, komunikasi, dan kesenian. Mereka mem-punyai pemahaman, program kegiatan, pelaksanaan terkait untuk mempertahankan, memperbaiki, dan mengembangkan unsur keperluan dan cara pemenuhannya dengan memperhatikan sumber daya manusia dan sumber daya alam di sekitarnya (Depsos 2006 dalam Permana, 2010:2).

Ridwan (2007: 27-38) memaparkan bahwa kearifan lokal (local wisdom) dapat dimaknai sebagai usaha manusia dengan menggunakan akal budinya (kognisi) untuk bartindak dan bersikap terhadap sesuatu, objek, atau peristiwa yang terjadi dalam ruang tertentu. Pengertian tersebut disusun secara etimologi. Lokal (local) secara spesifik menunjuk pada ruang interaksi terhad dengan sistem nilai yang terhad pula. Sebagai ruang interaksi yang sudah ditata sedemikian rupa menggambarkan suatu pola hubungan antara manusia dengan manusia atau manusia dengan lingkungan fisiknya. Pola interaksi yang sudah terdesain tersebut disebut setting. Setting adalah sebuah ruang interaksi tempat seseorang dapat menyusun hubungan-hubungan face to face dalam lingkungannya. Sebuah setting kehidupan yang sudah terbentuk secara langsung akan memproduksi nilai-nilai. Nilai-nilai tersebut yang akan menjadi landasan hubungan mereka atau menjadi acuan tingkah-laku mereka. Wisdom difahami sebagai ke-mampuan seseorang dalam mengguna-kan akal pikirannya dalam bartindak atau bersikap sebagai hasil penilaian terhadap sesuatu, objek, atau peristiwa yang terjadi. Sebagai sebuah istilah wisdom sering diartikan sebagai 'kearifan/kebijaksanaan'.

Sejalan dengan pendapat tersebut Saini (dalam Ridwan, 2007:1) mengatakan bahwa:

Kearifan lokal dalam bahasa asing sering dikonsepsikan sebagai ke-bijaksanaan lokal (local wisdom), pengetahuan lokal (local knowledge) atau kecerdasan lokal (local genius). Kearifan lokal adalah sikap, pandangan, dan kemampuan suatu komunitas di dalam mengelola lingkungan rohani dan jasmaninya, yang memberikan kepada komunitas itu daya tahan dan daya tumbuh di dalam wilayah dimana kumuniti itu berada. Dengan kata lain, kearifan lokal adalah jawaban kreatif terhadap situasi geografis, politik, historis, dan situasional yang bersifat lokal.

Kearifan lokal dipahami sebagai kearifan budaya lokal. Perhatikan pendapat Nashir (2003) berikut ini.

Kearifan budaya adalah energi potensial dari sistem pengetahuan kolektif masyarakat untuk hidup di atas nilai-nilai yang membawa kelangsungan hidup yang berper-adaban; hidup damai; hidup rukun; hidup bermoral; hidup saling asih, asah, dan asuh; hidup dalam keragaman; hidup penuh maaf dan pengertian; hidup toleran dan rendah hati; hidup harmoni dengan lingkungan; hidup dengan orientasi nilai-nilai yang membawa pada pencerahan; hidup untuk menyelesaikan persoalan-persoalan berdasarkan mozaik nalar kolektif sendiri. Kearifan seperti itu tumbuh dari dalam lubuk hati masyarakat sendiri. Itulah bagian terdalam dari kearifan kultur lokal. 
Sementara itu, dalam artikelnya yang bertajuk "Melestarikan Kearifan Masyarakat Tradisional (Indigenius Knowledge)" Hadi (2006) mengatakan bahwa pada dasarnya dalam setiap komunitas masyarakat memiliki kearifan lokal (local wisdom). Kearifan lokal merupakan suatu proses untuk 'menjadi pintar dan berpengetahuan' (being smart and knowledgeable)."

Secara umum, kearifan lokal (dalam situs Departemen Sosial RI) dianggap pandangan hidup dan ilmu pengetahuan serta berbagai strategi kehidupan yang berwujud aktivitas yang dilakukan oleh masyarakat lokal dalam menjawab berbagai masalah dalam pemenuhan keperluan mereka. Dengan pengertian-pengertian tersebut, kearifan lokal bukan saja berupa nilai tradisi atau ciri lokaliti semata, melainkan nilai tradisi yang mempunyai daya-guna untuk mewujudkan harapan atau nilai-nilai kemapanan yang juga secara universal yang didamba-dambakan oleh manusia.

Kearifan lokal merupakan penge-tahuan yang eksplisit yang muncul dari periode panjang yang berevolusi bersama-sama masyarakat dan lingkungannya dalam sistem lokal yang sudah dialami bersama-sama. Proses evolusi yang begitu panjang dan melekat dalam masyarakat dapat menjadikan kearifan lokal sebagai sumber energi potensial dari sistem pengetahuan kolektif masyarakat untuk hidup bersama secara dinamis dan damai. Pengertian ini melihat kearifan lokal tidak sekadar sebagai acuan tingkahlaku seseorang, tetapi lebih jauh, yaitu mampu mendinamisasi kehidupan masyarakat yang penuh keadaban.

Secara substansial, kearifan lokal itu adalah nilai-nilai yang berlaku dalam suatu masyarakat. Nilai-nilai yang diyakini kebenarannya dan menjadi acuan dalam bartingkah-laku seharihari masyarakat setempat. Oleh karena itu, sangat beralasan jika Greertz mengatakan bahwa kearifan lokal merupakan entiti yang sangat menentu-kan harkat dan martabat manusia dalam komunitasnya. Hal itu bermakna bahwa kearifan lokal yang berisi unsur kecerdasan kreativiti dan pengetahuan lokal dari para elit dan masyarakatnya adalah yang menentukan dalam pembangunan peradaban masyarakat-nya.
Keraf (2010:369) menyebut istilah kearifan lokal sebagai kearifan tradisional yang bermakna sebagai berikut.

Semua bentuk pengetahuan, keyakinan, pemahaman atau wawasan serta adat kebiasaan atau etika yang menuntun perilaku manusia dalam kehidupan di dalam komunitas ekologis. Jadi kearifan lokal ini bukan hanya merujuk kepada pengetahuan dan pemahaman masyarakat adat tentang manusia dan bagaimana relasi yang baik di antara manusia, melainkan juga berkaitan dengan pengetahuan, pemahaman, dan adat kebiasaan tentang manusia, alam, dan bagaimana relasi di antara semua penghuni komunitas ekologis ini harus dibangun. Seluruh kearifan tradisional ini dihayati, dipraktikkan, diajarkan dan diwariskan dari satu generasi ke generasi lain yang sekaligus membentuk pola perilaku manusia sehari-hari, baik terhadap sesama manusia maupun terhadap alam dan yang gaib.

Dari pengertian tersebut dapat disimpulkan bahwa: (1) kearifan tradisional adalah milik komunitas. Kearifan lokal yang dikenal sebagai pengetahuan tentang manusia, alam, dan relasi dengan alam merupakan milik komunitas. Tidak ada pengetahuan atau kearifan tradisional yang bersifat individual. (2) kearifan tradisional-dalam hal ini pengetahuan tradisional-lebih bersifat praktis. Pengetahu-an dan kearifan masyarakat adat adalah pengetahuan bagaimana hidup secara baik dengan semua isi alam. Pengetahuan ini juga mencakup bagaimana memperlakukan setiap bagian kehidupan dalam alam sedemikian rupa, baik untuk mempertahankan kehidupan masingmasing spesies maupun untuk mempertahankan seluruh kehidupan di alam itu sendiri. Oleh karena itu, selalu sahaja ada berbagai aturan yang sebahagian besar dalam bentuk larangan atau tabu tentang bagaimana menjalankan aktivitas kehidupan tertentu di alam ini. (3) Kearifan tradisional bersifat holistik, karena menyangkut pengetahuan dan pemahaman tentang seluruh kehidupan dengan segala relasinya di alam semesta. Alam adalah jaring kehidupan yang lebih luas dari sekadar jumlah keseluruhan bagian yang terpisah satu dengan yang lain. Alam adalah rangkaian relasi yang berkaitan satu dengan yang 
lainnya, sehingga pemahaman dan pengetahuan tentang alam harus merupakan suatu pengetahuan yang menye-luruh. (4) Kearifan lokal yang wujud dalam aktivitas masyarakat adat dipahami sebagai aktivitas moral. Kegiatan bertani, berburu, dan menangkap ikan bukanlah sekedar aktivitas ilmiah yang dituntun oleh prinsip-prinsip dan pemahaman ilmiah yang rasional. Aktivitas tersebut adalah aktivitas moral yang dituntun dan didasarkan pada prinsip atau tabu-tabu moral yang bersumber dari kearifan tradisional. (5) Kearifan tradisional bersifat lokal, karena terkait dengan tempat yang khusus dan konkret. Kearifan dan pengetahuan tradisional selalu mengenai pribadi manusia yang khas (komunitas masyarakat adat itu sendiri), alam lingkungan dan kaitannya dengan alam itu. Tetapi karena manusia dan alam bersifat universal, kearifan dan pengetahuan tradisional dengan tidak direkayasapun menjadi universal pada dirinya sendiri. Meskipun tidak memiliki rumusan universal sebagaimana dikenal dalam ilmu pengetahuan modern, kearifan tradisional ternyata ditemukan pada semua masyarakat adat atau suku asli di seluruh dunia, dengan substansi yang sama, baik dalam dimensi teknis maupun dalam dimensi moralnya.

Secara filosofis, kearifan lokal dapat diartikan sebagai sistem pengetahuan masyarakat lokal/ pribumi (indigenous knowledge systems) yang bersifat empiris dan pragmatis. Dikatakan bersifat empiris karena kearifan lokal merupakan hasil olahan masyarakat secara lokal yang bertumpu dari fakta-fakta yang terjadi di pesekitaran kehidupan mereka. Kearifan lokal dikatakan bersifat pragmatis karena seluruh konsep yang terbangun sebagai hasil dari olah fikir dalam sistem pengetahuan itu bertujuan untuk memecahkan masalah sehari-hari (daily problem solving).

Kearifan lokal merupakan sesuatu yang berhubung rapat secara spesifik dengan budaya lokal dan menggambarkan cara hidup suatu masyarakat lokal. Dengan kata lain, kearifan lokal merupakan bahagian budaya lokal (local culture). Budaya lokal (juga sering disebut budaya daerah) merupakan istilah yang biasanya digunakan untuk membedakan suatu budaya dari budaya nasional (Indonesia) dan budaya global. Budaya lokal adalah budaya yang dimiliki oleh masyarakat yang menempati kawasan atau daerah tertentu yang berbeda dari budaya yang dimiliki oleh masyarakat yang berada di tempat yang lain. Berdasarkan Peraturan Mentri Dalam Negeri Nomor 39 Tahun 2007 pasal 1 budaya daerah didefinisikan sebagai, "suatu sistem nilai yang dianut oleh komunitas atau kelompok masyarakat tertentu di daerah yang diyakini akan dapat memenuhi harapanharapan warga masyarakatnya dan di dalamnya ter-dapat nilai-nilai, sikap, tatacara masyarakat yang diyakini dapat memenuhi kehidupan warga masyarakatnya". Di Indonesia istilah budaya lokal juga sering disepadankan dengan budaya etnik/subetnik. Setiap bangsa, etnik, dan subetnik memiliki kebudayaan yang mencakup tujuh unsur, yaitu meliputi bahasa, sistem pengetahuan, organisasi sosial, sistem peralatan hidup dan teknologi, sistem mata pencaharian, sistem keagamaan, dan kesenian.

Secara umum, kearifan lokal (dalam situs Departemen Sosial RI) dianggap sebagai pandangan hidup dan ilmu pengetahuan serta berbagai strategi kehidup-an yang berwujud aktivitas yang dilakukan oleh masyarakat lokal dalam menjawab berbagai masalah dalam pemenuhan kebutuh-an mereka. Dengan pengertian-pengertian tersebut, kearifan lokal bukan hanya sekedar nilai tradisi atau ciri lokaliti semata, melain-kan nilai tradisi yang mempunyai daya-guna untuk untuk mewujudkan harapan atau nilai-nilai kemapanan yang ecara universal didamba-dambakan oleh manusia.

Kearifan lokal juga dimaknai sebagai nilainilai budaya yang baik yang ada di dalam suatu masyarakat. Hal ini berarti, untuk mengetahui suatu kearifan lokal di suatu kawasan, maka harus dapat memahami nilai-nilai budaya yang baik yang ada di dalam kawasan tersebut. Sebenarnya nilai-nilai kearifan lokal ini sudah diajarkan secara turun temurun oleh orang tua anak-anaknya. Budaya gotong royong, saling menghormati dan tepa salira merupakan contoh kecil dari kearifan lokal. Sudah selayaknya, generasi muda mencuba menggali kembali nilai-nilai kearifan lokal yang ada agar tidak punah dimamah perkembangan zaman. 
Dari berbagai definisi yang sudah dikemukakan, dapatlah dipahami bahwa kearifan lokal adalah pengetahuan yang dikembangkan oleh nenek moyang dalam mengubah suai lingkungan hidup di lingkungan mereka, menjadikan pengetahu-an itu sebagai bahagian dari budaya dan memperkenalkan serta meneruskannya dari generasi ke generasi. Beberapa bentuk pengetahuan tradisional itu muncul melalui cerita-cerita, legenda-legenda, nyanyian-nyanyian, ritual-ritual, dan juga aturan atau hukum lokal. Kearifan lokal menjadi penting dan bermanfaat hanya apabila masyarakat lokal yang mewarisi sistem pengetahuan itu mahu menerima dan mengukuhkan hal itu sebagai bahagian dari kehidupan mereka. Dengan cara itulah, kearifan lokal dapat disebut sebagai jiwa dari budaya lokal.

Kearifan lokal biasanya tercermin dalam kebiasaan-kebiasaan hidup masyarakat yang telah berlangsung lama. Keberlangsung-an kearifan lokal akan tercermin dalam nilai-nilai yang berlaku dalam kelompok masyarakat tertentu. Nilai-nilai itu menjadi pegangan kelompok masyarakat tertentu yang biasanya akan menjadi bahagian hidup tak terpisahkan yang dapat diamati melalui sikap dan perilaku mereka sehari-hari. Teezzi, dkk (dalam Ridwan, 2007:3) mengatakan bahwa "kemunculan kearifan lokal dalam masyarakat merupakan hasil dari proses trial and error, berbagai-bagai pengetahuan empiris maupun non-empiris atau yang estetik maupun intuitif".

Menurut perspektif kultural, kearifan lokal adalah berbagai nilai yang diciptakan, dikembangkan, dan dipertahankan oleh masyarakat yang menjadi pedoman hidup mereka. Termasuk berbagai mekanisme dan cara untuk bersikap, bartingkah laku dan bartindak yang dituangkan sebagai suatu tatanan sosial. Lebih lanjut Apriyanto dkk. (2008:4) menjelaskan bahwa terdapat lima dimensi kultural yang berkaitan dengan kearifan lokal. Kelima dimensi kultural tersebut meliputi pengetahuan lokal, budaya lokal, keterampilan lokal, sumber lokal, dan proses sosial lokal.

Pengetahuan lokal merupakan informasi dan data tentang karakter, keunikan lokal, serta pengetahuan dan pengalaman masyarakat untuk menghadapi masalah serta solusinya. Pengetahuan lokal penting untuk diketahui sebagai dimensi kearifan lokal sehingga diketahui derajat keunikan pengetahuan yang dikuasai oleh masyarakat setempat untuk menghasilkan inisiasi lokal.

Budaya lokal yaitu yang berkaitan dengan unsur-unsurkebudayaan yang telah terpola sebagai tradisi lokal. Tradisi lokal itu meliputi sistem nilai, bahasa, tradisi, dan teknologi. Keterampilan lokal ialah keahlian dan kemampuan masyarakat setempat untuk menerapkan dan memanfaatkan pengetahuan yang dimiliki.

Sumber lokal ialah sumber yang dimiliki masyarakat untuk memenuhi keperluan utamanya dan melaksanakan fungsi-fungsi utamanya. Proses sosial lokal berkaitan dengan bagaimana suatu masyarakat dalam menjalankan fungsifungsinya, sistem tindakan sosial yang dilakukan, tata hubungan social, serta kontrol sosial yang ada.

Bruce Mitchell, B. Setiawan, dan Dwita Hadi Rahmi (dalam Permana, 2010:4) menyatakan bahwa:

Konsep sistem kearifan lokal berakar dari sistem pengetahuan dan pengelolaan lokal atau tradisional. Karena hubungan yang dekat dengan lingkungan dan sumber daya alam, masyarakat lokal, tradisional atau asli, melalui "ujicoba" telah mengembangkan pemahaman terhadap sistem ekologi dimana mereka tinggal yang telah dianggap memper-tahankan sumber daya alam, serta meninggalkan kegiatan-kegiatan yang dianggap merusak lingkungan

Memperhatikan unsur-unsur yang membentuk kearifan lokal, Jim Ife (2002) berpendapat bahwa kearifan lokal memiliki lima bentuk atau dimenesi, yaitu: (1) pengetahuan lokal; (2) nilai lokal; (3) ke-terampilan lokal; (4) mekanisme peng-ambilan keputusan lokal; dan (5) solidariti kelompok lokal.

Pengetahuan lokal berkaitan dengan perubahan dan siklus iklim kemarau dan penghujan, jenis-jenis flora dan fauna, dan kondisi geografi, demografi, dan sosiografi. Hal ini terjadi karena masyarakat yang mendiami suatu daerah itu cukup lama dan telah mengalami perubahan 
sosial yang bervariasi menyebabkan mereka mampu beradaptasi dengan lingkungannya. Kemampuan beradaptasi ini menjadi bahagian dari pengetahuan lokal mereka dalam menguasai alam.

Nilai-nilai lokal mengatur kehidupan bersama antara warga masyarakat yang ditaati dan disepakati bersama oleh seluruh anggotanya. Nilai-nilai ini biasanya mengatur hubungan antara manusia dengan Tuhannya, manusia dengan manusia, dan antara manusia dengan alam. Nilainilai ini memiliki dimensi waktu berupa nilai masa lalu, masa kini, dan masa datang. Nilainilai tersebut akan mengalami perubahan sesuai dengan kemajuan masyarakatnya.

Keterampilan lokal bagi setiap masyarakat dipergunakan sebagai kemampu-an untuk bertahan hidup (survival). Ke-terampilan lokal dari yang paling sederhana seperti berburu, meramu, bercocok tanam sampai membuat industri rumah tangga. Keterampilan lokal ini biasanya hanya cukup dan mampu memenuhi keperluan keluarga-nya masing-masing atau disebut dengan ekonomi subsistensi.

Sumber daya lokal pada umumnya adalah sumber daya alam, yaitu sumber daya yang alam yang tak dapat diperbaharui dan dapat diperbaharui. Masyarakat akan meng-gunakan sumber daya lokal sesuai dengan keperluannya dan tidak akan mengeksploitasi secara besarbesaran atau dikomersilkan. Sumber daya lokal ini sudah dibagi peruntuk-kannya seperti hutan, kebun, sumber air, kawasan pertanian, dan pemukiman. Kepemilikan sumber daya lokal ini biasanya bersifat kolektif.

Setiap masyarakat pada dasarnya memiliki pemerintahan lokal sendiri yang dikenal dengan pemimpin suku. Masing-masing masyarakat mempunyai mekanisme pengambilan keputusan yang berbeda. Ada masyarakat yang melakukan secara de-mokratis atau duduk sama rendah berdiri sama tinggi. Ada juga masyarakat yang melakukan demokrasi itu secara bartingkat.

Masyarakat pada umumnya dipersatukan oleh ikatan komunal untuk membentuk solidaritas lokal. Setiap masyarakat mempunyai medium untuk mengikat warganya, misalnya melalui ritual keagamaan dan upacara adat lainnya.
Masing-masing anggota masyarakat saling memberi dan menerima sesuai dengan bidang dan fungsinya masing-masing seperti dalam solidaritas mengolah tanaman padi dan kerja bakti, bergotong royong.

\section{METODOLOGI PENELITIAN}

Kajian sastra, apapun bentuknya, selalu berhubungan dengan pemaknaan. Pemaknaan ini dapat ditinjau dari berbagai aspek sesuai dengan keperluan kajian. Legenda sebagai bagian dari cerita rakyat menggambarkan perikehidupan masyarakat di mana karya sastra itu hidup. Dengan mengkaji legenda secara mendalam dapat ditemui makna simbol-simbol kearifan lokal yang terdapat di dalumumnya. Untuk melakukan pengkajian tersebut metodologi kajian diperlukan sebagai pemandu dalam penelitian ini. Proses pemaknaan terhadap simbol-simbol kearifan lokal dapat dilakukan dengan menggunakan berbagai pendekatan yang dianggap sesuai. Hermeneutika merupakan satu di antara pendekatan yang dapat digunakan untuk memaknai sebuah karya sastra. Hermeneutika adalah ilmu penafsiran atau interpretasi terhadap teks pada khususnya dan penafsiran bahasa pada umumnya.

Metode yang digunakan dalam penelitian ini adalah metode deskriptif. Dengan metode deskriptif data penelitian dianalisis dan diuraikan menggunakan kata-kata ataupun kalimat dan bukan dalam bentuk angka-angka atau mengadakan perhitungan. Data penelitian ini diperoleh melalui kajian mendalam terhadap dokumen yang tersedia dalam bentuk cerita rakyat. Dalam hal ini metode deskriptif akan digunakan untuk mendeskripsikan atau menggambarkan suatu gejala, peristiwa, kejadian, yang terdapat sewaktu penelitian dilakukan terhadap objek kajian. Data dalam penelitian deskriptif menurut Moleong (2002: 6) berupa kata-kata, gambaran, dan bukan angka-angka.

Bentuk penelitian ini adalah kualitatif, yaitu bentuk penelitian yang mengutamakan proses atau prosedur yang dijalankan, sedangkan hasilnya bergantung pada proses penelitian itu sendiri. Pendapat ini berdasar pada teori yang disampaikan oleh Bogdan dan Biklen, Lincoln dan Guba dalam Moleong (2002:4-8) bahwa 
bentuk penelitian kualitatif terdiri dari sebelas karakteristik yaitu: 1) latar alamiah, manusia sebagai alat, 3) metode kualitatif, 4) analisis secara induktif, 5) teori dari dasar, deskriptif, 7) lebih mementingkan proses dari hasil, 8) adanya "Batas" yang ditentukan oleh "fokus", 9) adanya kriteria khusus untuk keabsahan data, 10) desain bersifat sementara, 11) hasil penelitian dirundingkan dan disepakati bersama.

Pendekatan yang digunakan dalam penelitian ini adalah pendekatan hermeneutika menurut pemikiran Paul Riceour. Pendekatan hermeneutika pada prinsipnya merupakan kajian yang mendalam terhadap teks dengan menafsir simbol-simbol yang ada di dalam teks tersebut. Proses pemaknaan dilakukan melalui tahap penjelasan (explanation) yang merujuk kepada konteks linguistik dan dilanjutkan dengan tahap penafsiran (interpretation) yang merujuk kepada konteks ekstra-linguistik. Paul Ricoeur menamakan langkah kerja pendekatan ini sebagai depth semantic. Makna teks tidak akan diperoleh apabila tidak dilakukan pembacaan dan interpretasi terhadap teks tersebut. Dalam hal ini, Paul Ricoeur (2002:223) menempatkan explanation dan interpretation pada garis yang linear. Analisis explanation dapat digunakan sebagai tahap awal untuk mengkaji dimensi statis teks, sedangkan interpretation digunakan seterusnya untuk menangkap makna kontekstual dari teks tersebut. Sehubungan dengan penjelasan ter-sebut Paul Ricoeur (2002:161-162) mengatakan, "... to explain is to bring out the structure, that is, the internal relations of dependence which constitute the static of the text; to interpret is to follow the path of thought opened up by the text, to place oneself en route toward the orient of the text."

Pemaknaan terhadap simbol-simbol mengharuskan peneliti melibatkan seluruh kemampuan dan kecakapannya dengan memanfaatkan konteks linguistik dan konteks non-linguistik sehingga peneliti tidak hanya menangkap sense tetapi mampu memperoleh reference dari penafsiran tersebut. Dengan demikian peneliti mampu melakukan refigurasi, memaknai simbol-simbol secara baru sebagai hasil penafsiran yang dilakukan.

Menurut Ricoeur (1984:54-75), kegiatan membaca atau menginterpretasi memberi orientasi baru kepada pembaca tentang bagaimana manusia hadir melalui tindakan-tindakannya dalam dunia nyata. Melalui tindakan-tindakan refigurasi oleh pembaca, keberadaan manusia dalam dunia pembaca diberi figur yang baharu. Pembaca berada (eksis) secara baru dan mendasar di dunia melalui tindakan-tindakan baru (inisiatif) dan termasuk di dalumumnya tindakan-tindakan etis (eksistensi). Yang diciptakan oleh cerita bukan makna (sense) tetapi reference. Dalam refigurasi, manusia dikirim kembali ke dunia nyata setelah ditarik ke dalam dunia cerita.

Instrumen dalam penelitian ini adalah peneliti sendiri, hal ini berlandas pada sebuah pendapat bahwa dalam penelitian kualitatif yang menjadi instrumen adalah peneliti itu sendiri. Penelitian kualitatif men-jadikan manusia sebagai alat (instrumen), artinya dalam penelitian kualitatif manusia (peneliti atau dengan batuan orang lain) bartindak sebagai instrumen atau alat utama baik dalam pengumpulan data, pencatatan data, maupun dalam hal penafsiran data dengan mengerahkan segenap kemampuan intelektual pengetahuan, dan keterampilan yang dimiliki terhadap fenomena yang ada (Bogdan dan Biklen, Lincoln dan Guba dalam Moleong, 2002:48). Dengan demikian peneliti disebut sebagai instrumen utama atau alat pengumpul data utama. Untuk memudah-kan pengumpulan data maka peneliti meng-gunakan alat bantu penelitian yaitu kartu pencatat data. Alat bantu yang digunakan peneliti dimaksudkan untuk mempermudah peneliti dalam mengumpulkan data supaya data yang diambil lengkap dan sesuai dengan fakta. Selanjutnya kartu pencatat data, ini disebut sebagai alat bantu.

Teknik pengumpulan data dalam penelitian ini adalah teknik studi dokumenter. Penggunaan teknik tersebut didasarkan pada pemanfaatan dokumen yang berbentuk legenda, yaitu cerita Ne' Baruakng Kulup dan Ria Sinir yang sudah direkam dan sudah berwujud dokumen.

Sumber data dalam penelitian ini berupa dokumen, yaitu teks cerita rakyat Dayak Kanayatn yang berjudul $N$ ' Baruakng Kulup dan Ria 
Sinir. Data penelitiannya berupa tradisi-tradisi, kepercayaan, dan nilai-nilai yang menunjukkan kearifan lokal dalam legenda Dayak Kanayatn.

Prosedur kerja pendekatan hermeneutika menempatkan peneliti sebagai penafsir. Hal pertama yang harus dilakukan adalah mengidentifikasi simbol-simbol yang ada dalam sebuah teks. Teks yang dimaksudkan di dalam penelitian ini adalah teks legenda Dayak Kanayatn dan simbol-simbol yang dimaksudkan adalah ialah simbol spiritual dari kearifan-kearifan lokal yang terkandung dalam legenda yang diteliti. Simbol-simbol spiritual kemudian dimaknai berdasarkan konteks yang ada dalam legenda yang diteliti. Pada tahap ini pemaknaan terhadap simbol spiritual dari kearifan lokal baru sampai pada tingkat penjelasan (eksplanasi). Untuk menemukan makna terdalam yang tersembunyi dalam simbol spiritual, maka dilakukan proses menafsirkan terhadap simbol-simbol spiritual. Prosedur kerja kajian hermeneutika dianggap selesai apabila penafsir telah menemukan makna terdalam darisetiap simbol yang dianalisis. Dalam hal ini peranan penafsir sangat dominan. Oleh karena itu, penafsir harus mampu menggali makna terdalam dari setiap symbol spiritual dari kearifan lokal yang dianalisisnya dengan memanfaatkan pengalaman, pengetahuan, dan wawasan yang dimilikinya.

Penerapan prosedur kerja kajian hermeneutika dalam penelitian ini melalui tahaptahap berikut ini.

1. Membaca secara cermat legenda Ne' Baruakng Kulup dan Ria Sinir yang telah ditetapkan sebagai objek kajian.

2. Mengidentifikasi dan menganalisis tradisitradisi yang menunjukkan kearifan lokal masyarakat Dayak Kanayatn yang terdapat dalam legenda Ne' Baruakng Kulup dan Ria Sinir.

3. Mengidentifikasi dan menganalisis kepercayaan yang menunjukkan kearifan lokal masyarakat Dayak Kanayatn yang terdapat dalam legenda Ne' Baruakng Kulup dan Ria Sinir.

4. Mengidentifikasi dan menganalisis nilainilai yang menunjukkan kearifan lokal masyarakat Dayak Kanayatn yang ter-dapat dalam legenda Ne' Baruakng Kulup dan Ria Sinir.

5. Mentafsirkan simbol-simbol spiritual dari kearifan lokal dalam legenda Ne' Baruakng Kulup dan Ria Sinir dengan menggunakan kajian hermeneutika.

6. Menyimpulkan hasil analisis dan hasil penafsiran terhadap simbol-simbol spiritual dari kearifan lokal dalam legenda $\mathrm{Ne}^{\prime}$ Baruakng Kulup dan Ria Sinir.

7. Melaporkan hasil penelitian.

\section{SIMPULAN DAN SARAN}

Bahasa merupakan satu di antara sekian banyak simbol. Sebagai sebuah simbol, kata-kata memiliki makna dengan intensi tertentu. Melalui pentafsiran, misteri yang terdapat dalam sebuah simbol (kata-kata) dapat diungkapkan dengan membuka selubung makna yang belum diketahui dan ter-sembunyi di dalam simbol-simbol tersebut. Simbol mengundang penafsir untuk berpikir sehingga simbol itu sendiri menjadi kaya dengan makna. Simbol adalah lambang yang mewakili nila-nilai tertentu. Meskipun simbol bukanlah nilai itu sendiri, namun simbol sangat diperlukan untuk kepentingan peng-hayatan terhadap nilai-nilai yang diwakilinya. Simbol boleh digunakan untuk apa saja. Misalnya, untuk ilmu pengetahuan, kehidup-an sosial, dan keagamaan. Bentuk simbol tidak hanya berupa benda yang dapat dilihat, tetapi dapat berupa gerakan dan ucapan.

\section{Simpulan}

Dalam penelitian ini, simbol yang tidak berwujud yang bersifat abstrak dinamakan sebagai simbol spiritual. Setelah dianalisis ditemukan lima belas simbol spiritual yang meliputi (1) tradisi-tradisi (berkhitan, mengayau, notokng, baliatn, perkawinan, perceraian); (2) kepercayaan (Jubata, nyangahatn, kekuatan gaib, tariu); (3) nilai-nilai lokal (musyawarah, solidaritas, patuh pada aturan adat, persahabatan, dan kekerabatan). Kelima belas simbol spiritual tersebut ditafsirkan dengan menggunakan pendekatan hermeneutika dan diperoleh makna yang cukup beragam yakni 44 makna.

Keempat puluh empat makna tersebut 
dikelompokkan ke dalam lima kategori berikut ini: (1) makna yang berkaitan dengan kepercayaan warisan, (2) makna yang berkaitan dengan tradisi dan adat istiadat, (3) makna yang berkaitan dengan alam sekitar, (4) makna yang berkaitan dengan perilaku hidup bermasyarakat, dan (5) makna yang berkaitan dengan musyawarah.

\section{Saran}

Model penelitian ini memberi sumbangan kepada para peneliti apabila hendak menggunakan kajian hermeneutik dalam kajiannya. Kajian ini telah mem-buktikan bahwa bahan-bahan lokal, seperti legenda maupun kearifan lokal dapat dikaji dengan memanfaatkan kajian-kajian filsafat barat seperti kajian hermeneutika ini. Model kajian ini dapat dimanfaatkan untuk membina dan mengembangkan bengkel penelitian bagi mahasiswa dalam mengikuti mata kuliah sastra, secara lebih khusus pada mata kuliah Sastra Daerah, Sosiologi Sastra, Sastera Bandingan, dan Kajian Prosa. Kearifan-kearifan lokal dan legenda dapat dimanfaat-kan sebagai bahan pembelajaran di sekolah maupun di perguruan tinggi, sebagai bahan kajian dalam penelitian, dan dapat dimanfaatkan sebagai bahan muatan lokal untuk membina akhlak dan moral para pelajar.

Penyelidikan ini difokuskan pada aspekaspek kearifan lokal, penafsiran ter-hadap simbolsimbol spiritual dari kearifan lokal masyarakat Dayak Kanayatn yang terdapat dalam legenda. Pengkajian secara mendalam tehadap simbolsimbol kearifan lokal sangat bermanfaat bagi masyarakat terutama masyarakat Dayak Kanayatn karena mengandung nilai-nilai kebajikan yang selain bermakna lokal tetapi dijumpai juga nilainilai kehidupan yang bermakna universal.

Kajian lanjutan mengenai kearifan lokal masyarakat Dayak Kanayatn dalam bidang yang lebih luas dengan memanfaatkan berbagai sumber yang tersedia di dalam masyarakat, tidak hanya menggunakan legenda sebagai korpus datanya. Dengan demikian diperoleh kajian yang lebih komprehensif mengenai kearifan lokal yang masih hidup dalam masyarakat Dayak Kanayatn.

Kajian yang lebih intensif mengenai bagaimana masyarakat Dayak Kanayatn menyusun pengetahuan lokal, nilai-nilai lokal, dan teknologi lokal sehingga mereka dapat mempertahankan eksistensinya dalam menghadapi zaman yang terus berubah dari masa ke masa dan mereka tidak kehilangan jati dirinya.

\section{DAFTAR PUSTAKA}

Ayatrohaedi, H. (Ed.). 1986. Kepribadian Budaya Bangsa (Local Genius). Jakarta: Pustaka Jaya.

Bleicher, J. 1980. Contemporary Hermeneutics, Hermeneutics as Method, Philosophy, and Croitique.London: Rutledge \&Kegan Paul

Brunvand, Jan Harold. 1968. The Study of American Folklore-An Introduction. New York: W.W. Norton 7 Co. Inc.

Danandjaja, James. 1994. Folklor Indonesia Ilmu, Gosip, Dongeng, dan lain-lain. Jakarta: Grafiti Press.

Dorson, R.M. (Ed.). 1968. Peasant Customs and Savage Myths. London: Routledge and Kegan Paul.

Dundes, A. 1965. The Study of Folklore. Englewood Cliff, New Jersey: Prentice Hall, Inc

Endraswara, Suwardi. 2008. Metodologi Penelitian Sastra Epistimologi, Model, Teori, dan Aplikasi. Yogyakarta: MedPress.

Herry, Masnur. 2012. Teori Interpretasi Memahami Teks, Penafsiran, dan Metodologinya. Yogyakarta: IRGiSoD.

Hidayat, Arif 2012. Aplikasi Teori Hermeneutika dan Wacana Kritis.Purwekerto: STAIN Press.

Hutomo, Suripan Sadi . 1991. Mutiara yang Terlupakan Pengantar Studi Sastra Lisan. Surabaya: HISKI-Komisariat Jawa Timur.

Ife, Jim. 2003. Community Development, Creating Community Alternatif Vision Analysis and Practice. Australia: Longmann.

Kaelan. 2009. Semiotika dan Hermeneutika. Jakarta: Gramedia Pustaka Utama

Keraf, A.S. 2010. Etika Lingkungan Hidup. Jakarta: Penerbit Buku Kompas

Koentjaraningrat. 1985. Pengantar Ilmu Antropologi. Jakarta: Aksara Baru.

Krohn, K. 1971. Folklore and Methodology. Austin \& London: The University of Texas. 
Mariane, Irene. 2013. Kearifan Lokal Pengelolaan Hutan Adat. Jakarta: PT Raja Grafindo Persada.

Moeis, Diana Nimpoeno. 1991. "Makna Folklor Sangkuriang sebagai Karya Sastra Lisan dan Fungsi dalam Masyarakat Sunda (Studi Kasus di Kotamadya Bandung)". Disertasi. Bandung: Universitas Padjadjaran.

Moleong, Lexy J. 2005. Metode Penelitian Kualitatif. Bandung: Remaja Rosda Karya.

Muhrotien,Andreas.2012. Rekonstruksi Identitas Dayak. Yogyakarta: TICI Publication

Nashir, Haedar. 2003. Menggali Kearifan Menghalau Kerakusan (Online).

(http://www.republika.co.id/koran_detail. asp?id $=116166 \&$ kat_id $=49 \&$ kat_id1 $=\& k a t$ id2= diakses tanggal 31 Oktober 2012)

Permana, R. Cecep Eka. 2010. Kearifan Lokal Masyarakat Baduy dalam Mitigasi Bencana. Jakarta: Wedatama Widya Sastra.

Piah, Harun Mat at all, 2006. Kesusasteraan Melayu Tradisional. Kuala Lumpur: Dewan Bahasa Dan Pustaka.

Piah, Harun Mat at all, 2006. Kesusasteraan Melayu Tradisional. Kuala Lumpur: Dewan Bahasa Dan Pustaka.

Ricoeur, P. 1975. Theory of Interpretation: Discourse and The Surplus of Meaning. Texas: The Texas Christian University Press. Diterjemahkan oleh Musnur Hery. 2003. Filsafat Wacana: Membelah Makna dalam Anatomi Bahasa. Yogyakarta: IRCiSoD.

Ricoeur, P. 1981. Hermeneutics \& The Human Sciences. New York: The Press Syndicate of The University of Cambridge.

Ricoeur, P.1991. Reflection and Imagination: A Ricour Reader. (Penyunting Mario J. Valdes) New York: Harvester Wheatsheaf.

Ricoeur, P.1994. Time and Narrative. Volume 2. Translated by Kathleen McLaughin and David Pellauuer. Chicago and London: The University of Chicago Press.

Ricoeur, P.1995. Hermenuutics and The Human Sciences. Edited and translated by Jhon B.
Thompson. Paris: Cambridge University Press.

Ricoeur, P.1997. Time and Narrative. Volume 3. Translated by Kathleen McLaughin and David Pellauner. Chicago and London: The University of Chicago Press.

Ricoeur, P.1997. The Rule of Metaphor MultiDisciplinary Studies of The Creation of Meaning in Language. Translated by Robert Czerny, Translated by Kathleen McLaughin and John Castello, SJ. London: Routledge 11 New Fetter Lane.

Ricoeur, P.1998. Critique and Conviction. Translated by Kathleen Blamey. France: Polity Press.

Ricoeur, P. 2000. The Just. USA: The University of Chicago Press.

Ricoeur, P. 2004. Memory, History, Forgetting. Translated by Kathleen McLaughin and David Pellauuer. Chicago and London: The University of Chicago Press.

Ricoeur, P.2012. Teori Interpretasi Memahami Teks, Penafsiran, dan Metodologinya. Diterjemahkan oleh Musnur Herry. Yogyakarta: IRGiSoD.

Ridwan, N.A. 2007. "Landasan Keilmuan Kearifan Lokal". Jurnal Studi Islam dan Budaya. Vol.5, (1), 27-38.

Sobur, Alex. 2001. Analisis Teks Media Suatu Pengantar untuk Analisis Wacana, Analisis Semiotik, dan Analisis Framig. Bandung: PT Remaja Rosdakarya

Spradley, J. P. 2007. Metode Etnografi. Edisi Kedua. Yogyakarta: Tiara wacana.

Sumaryono, E. 1999. Hermeneutik: Sebuah Metode Filsafat.Yogyakarta: Kanisius Titib, I Made 2001. Teologi dan SimbolSimbol Praktis Kehidupan. Surabaya: Paramita

Valdes, M.J. 1987. Phenomenological, Hermeneutical, Hermeneutics and the Study of Literature. London: University of Toronto Press,

Vardiansyah, Dani. 2008. Filsafat Ilmu Komunikasi: Suatu Pengantar. Jakarta: Indeks. 